\title{
Elemental content profiles in propolis from several cities of Turkey
}

\author{
Canan Aksoy, Meltem Maras Atabay ${ }^{2 *}$, Engin Tirasoglu³, \\ Ezgi Taylan Koparan², Aysel Kekillioglu4
}

${ }^{1}$ Faculty of Technology, Department of Electronics and Communication Engineering, Karadeniz Technical University, Trabzon, Turkey; ${ }^{2}$ Faculty of Education, Department of Mathematics and Science Education, Bulent Ecevit University, Kdz. Eregli, Zonguldak, Turkey; ${ }^{3}$ Faculty of science, Department of Physics, Karadeniz Technical University, Trabzon, Turkey; ${ }^{4}$ Faculty of Science, Department of Biology, NevsehirHaci BektasVeli University, Nevsehir, Turkey

Corresponding author: Bulent Ecevit University, Faculty of Education, Department of Mathematics and Science Education, Kdz. Eregli, Zonguldak, Turkey

Submission Date: April 12 $2^{\text {nd }}, 2017$, Acceptance Date: August 27 $7^{\text {th }}$, 2017, Publication Date: August $31^{\text {st }}, 2017$

Citation: Aksoy C, Atabay M, Tirasoglu E, Koparan E, Kekillioglu A. Elemental content profiles in propolis from several cities of Turkey. Functional Foods in Health and Disease 2017; 7(8); 661-670.

\begin{abstract}
Background: Macro-element content profiles in propolis that have been previously used in traditional folk medicine have provided enough information to develop a classification of the geological origin of propolis. Within this study, we aim to contribute our research to existing literatüre, particularly through our use of EDXRF spectroscopy, which has not been used to study propolis before. The results of the study led us to conclude that the residues of heavy metals were a limited concentration in Turkish propolis samples.
\end{abstract}

Objective: The purpose of this study was to investigate the macro-element profiles in Turkish propolis from 18 different cities of Turkey.

Methods: The macro-element of 22 raw propolis samples were investigated using EnergyDispersive X-ray fluorescence spectrometry.

Results: Turkish Propolis was discovered to be rich with minerals of potassium, sodium which could be more beneficial in human nutrition. Potassium content was at a relatively higher level than other elements in these samples, while calcium content was at alower level in those samples from various regions of Turkey.

Conclusion: The elements of propolis that we studied were distinctive enough to make the discrimination of propolis from different locations in Turkey possible. The quantification by 
energy-dispersive X-ray fluorescence spectrometry procedures provided good resolution of multielement analysis in propolis samples.

Keywords: Propolis; element analysis; energy-dispersive X-ray fluorescence spectrometre

\section{INTRODUCTION}

Propolis is a naturopathic formulation collected by honeybees from the buds and exudates of conifer trees and plants. The composition of the propolis depends upon the vegetation of the area from which it was collected; however, due to its botanical origins and its resulting variations, there may be difference in the chemical composition of samples from different locations, even those from the same locality [1]. Propolis is used by the bees as a protective barrier in hives. Propolis is collected from plants by honeybees, and has anti-mutagenic and anti-carcinogenic properties in addition to biological and therapeutic effects [2, 3, 4]. Bees use the propolis to protect and reinforce their hives, repair their hive structure, and to cover honeycombs. It kills pathogens, serves as protection against rain due to its stickiness, and prevents undesirable guests from entering the hive $[4,5]$. However, not all species of bees produce this bee glue to the same degree $[5,6]$. The content of extract and element indicates enviromental differences.

Propolis, a natural product derived from plant resins collected by honeybees, has been used in traditional medicine all over the world for thousands of years. Accordingly, propolis has also gained popularity as a health drink and has been extensively used in foods to improve overall health and prevent diseases [2, 9-11].

However, traces of certain metals can also cause a variety of undesirable changes in propolis preparations during their formation and storage. Among its trace elements, chromium, iron, and zinc were the most common. Trace and macro-element profiles in propolis provided enough information to develop the classification of the geological origin of propolis [7]. The chemical composition of propolis varies greatly and depends directly on the local flora and phenology of the host plants, and indirectly on the locality and time of collection. Thus, the wide variability in the chemical composition of propolis makes it more essential [12]. There have been several studies related to the chemical components of different provinces of Turkish propolis which have provided valuable information on this topic [13-18]. Therefore, there has been significant investigation on the preclinical investigation of propolis in some provinces of Turkey [16, 19, 20-23, 29]. Through this study, we hope to make a contribution to exisitng research literature by using EDXRF spectroscopy, which has not been used for propolis studies thus far.

In this study, we obtained propolis from 22 different provinces to compare the essential element contents of these 22 raw propolis samples in different phyto-geographical regions in Turkey. We used Energy-Dispersive X-ray fluorescence (EDXRF) spectrometry to determine the element content of propolis. The samples were collected from several honey bee farms in Turkey.

\section{MATERIALS AND METHODS}

\section{Propolis samples}

Propolis samples were collected from several cities of Turkey (Adana, Ankara, Aydın, Bartın, Bilecik, Bolu, Düzce, Burdur, Bursa, Erzurum, Karabük, Kastamonu, Kırıkkale, Muş, Sivas, Trabzon, Van, and Zonguldak), which can be seen on the Turkey map in Figure 1. Materials were obtained from these cities from May 2015 to September 2015. The products were collected from 
the apiaries of three bee colonies. The samples were combined into an one-pooled propolis. Propolis was collected directly from the hives. Samples were maintained at $-20^{\circ} \mathrm{C}$ before processing.

\section{Sample Preparation (EEP) of Propolis}

$10 \mathrm{gr}$ of propolis samples were dissolved in $100 \mathrm{ml}$ of $96 \%$ ethanol and incubated for $24 \mathrm{~h}$ at $60^{\circ} \mathrm{C}$. After incubation, the sample was centrifuged for $10 \mathrm{~min}$ at $4000 \mathrm{rpm}$. The supernatan was filtered and evaporated to dryness in a rotavapor.

\section{Element analysis}

EDXRF is an excellent non-destructive method to determine the elemental content of a sample. The elemental concentration of the samples was determined using a Skyray EDX3600B spectrometer equipped with an Oxford Rh anode X-ray tube. The spectrometer has a SSD detector made in Germany which has $145 \pm 5 \mathrm{eV}$ energy resolutions. This spectrometer is capable of $0.05 \%$ measurement precision, analytical range of elements from Sodium to Uranium, and ppm-99.99\% analysis range. Moreover, 24 elements can be analyzed simultaneously using it. The standardization of the samples was conducted using Panalytical AXIOS Advanced WDXRF. In the work of standardization, the IQ+ program was used since this program gives the semiquantitative results with $95-90 \%$ precision for all materials. The standard curves were drawn at the EDX3600B spectrometer using the standard values which were obtained from the IQ+ program and uploaded to the system. The concentration of the samples was determined by the system using these standard curves. It is possible to measure the sample with solid or liquid. Accordingly, current samples were measured as a solid target by being pressed at a five tone hydraulic press that compressed the sample powder into a solid thick pellet of $40 \mathrm{~mm}$ diameter using a boric acide (H3BO3-powder) as a protective cover.

\section{Heavy Metal Analysis}

Studies were performed at a constant temperature of $25^{\circ} \mathrm{C}$ to be representative of environmental conditions. All propolis samples were lyophilized and dried. Next, dried samples were added to 5 $\mathrm{ml}$ püre nitric acid and $5 \mathrm{ml}$ hydrogen perocside. This mixture was heated for 6 hours. The solution was cooled and filtered. Then the solution was analyzed using Atomic Adsorption Spectrometer (GBC 933 AAA). The amount of heavy metal ( $\mu \mathrm{g} / \mathrm{kg}$ ) was also calculated (Matin, 2014).

\section{Statistical analysis}

The differences in element composition in the 22 raw propolis samples from Turkey were evaluated by non-parametric Kruskal Wallis test of one-way analysis of variance (ANOVA). $\mathrm{p}<0.05$ was considered significant. SPSS 10 software was used for analyses.

\section{RESULTS AND DISCUSSION}

Propolis is an important apicultural product with various chemical compositions and several pharmacological and nutritional applications. Moreover, it is a mixture of compenents collected by bees discovered to have diverse biological properties. The content of propolis has been 
discovered to be linked to the normal surrounding habitat, weather, and season collection. Diversity in chemical composition of propolis reflect the floral richness and the climate differences in the country [24].

The different polyphenol concentrations in raw material are essential for standardization and categorization of raw material propolis. Geographical molecular marker is also important for analyzing the location where each propolis sample was taken from [11, 25-26]. The composition of propolis is dependent on the flora, season, and time of the collection [27]. Consequently, it could be suggested that the element content may help determine additional qualities of propolis samples. However, apart from the analysis of natural propolis constituents, elements and toxic contaminants such as heavy metals can also be a subject of chemical control [12].

In this study, the aim was to evaluate the micro/macro elements and heavy metal contents of raw propolis samples originating from different locations of Turkey using energy-dispersive $\mathrm{X}$ ray fluorescence (EDXRF) spectrometry. Thus, as seen in Figure 1, propolis samples collected from different regions of Turkey were analyzed.

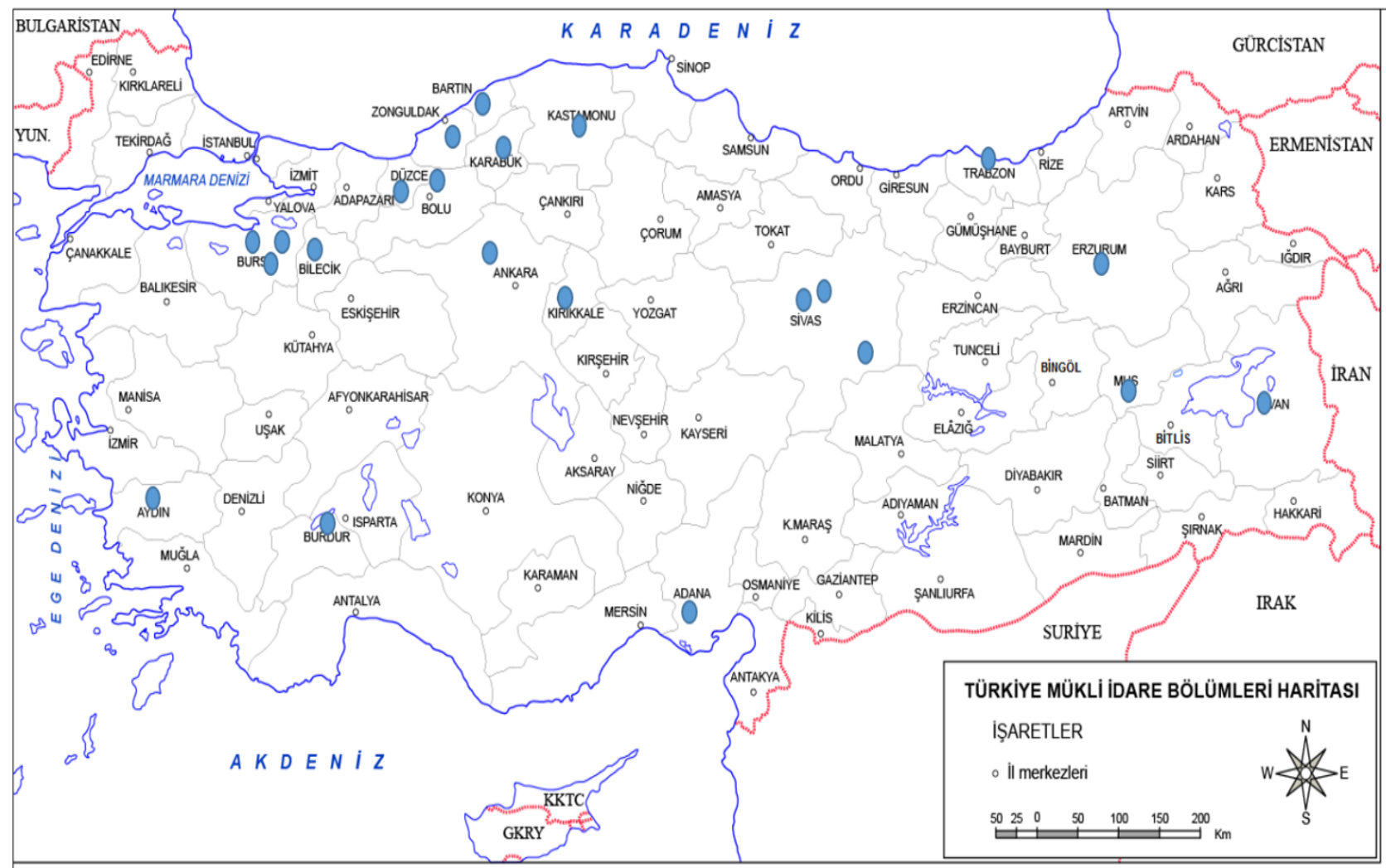

cografyaharita.com R. SAYGILI 2015

Figure 1. Turkey map shows the cities where the propolis samples were collected

Obtained samples have a wide distribution in Turkey and have been cultivated by farmers from private lands for centuries [28].

Propolis produced by bees is a 50-70\% mixture of resins and balsams, 30-50\% wax, 5-10\% polen, and $10 \%$ essential oils, also being mixed with the bee's salivary excretions. Propolis wax 
contains amino acids, with the major amino acids being glutamic acid. The average of wax in raw Turkish propolis is $41 \% \pm 22.2$ and the average of moisture in it is $2.1 \%$ (Table 1 ).

Table 1. Physicochemical properties of 22 raw propolis samples from various region of Turkey

\begin{tabular}{|l|c|c|c|}
\hline & Wax \% & Ash \% & Moisture \% \\
\hline Average & 41.0 & 1.7 & 2.1 \\
\hline Std. Dev. & 22.2 & 1.0 & 1.1 \\
\hline Minimum & 5.3 & 0.2 & 0.5 \\
\hline Maximum & 75.9 & 4.2 & 3.1 \\
\hline
\end{tabular}

The samples and reagents were prepared daily in order to avoid losses and contamination. In most of the analyzed samples, $\mathrm{Si}, \mathrm{Na}, \mathrm{Mg}, \mathrm{Al}, \mathrm{K}, \mathrm{Fe}, \mathrm{Cu}, \mathrm{Zn}$ and $\mathrm{Mn}$ were observed.

Table 2. Concentration of elements in propolis (N: 22, \%) by using Energy-Dispersive X-ray fluorescence (EDXRF) spectrometry.

\begin{tabular}{|l|c|c|c|c|c|c|c|c|c|}
\hline & $\mathbf{M g}$ & $\mathbf{N a}$ & $\mathbf{A l}$ & $\mathbf{S i}$ & $\mathbf{S}$ & $\mathbf{K}$ & $\mathbf{C a}$ & $\mathbf{F e}$ & $\mathbf{M n}$ \\
\hline Ankara -Kızılcahamam & 0 & 0.13 & 0.08 & 0.63 & 0 & 0.51 & 0 & 0.02 & 0.21 \\
\hline Kırıkkale & 0.02 & 0.19 & 0.12 & 0.99 & 0.15 & $\mathbf{0 . 9 1}$ & 0 & 0.03 & 0.22 \\
\hline Sivas -Divriği & 0 & 0.11 & 0.05 & 0.44 & 0.10 & 0.14 & 0 & 0.02 & 0.22 \\
\hline Sivas-Zara & 0.03 & $\mathbf{0 . 3 0}$ & 0.11 & 1.89 & $\mathbf{0 . 2 9}$ & 0.50 & 0.35 & 0.02 & 0.23 \\
\hline Sivas & 0 & 0.22 & 0.08 & 1.26 & 0 & 0.14 & 0 & 0.03 & 0.21 \\
\hline Burdur & 0 & 0.20 & 0.06 & 1.23 & 0 & 0.45 & 0.03 & 0.03 & 0.20 \\
\hline Bursa-Kemalpaşa & 0 & 0.08 & 0.09 & 0.23 & 0 & 0.03 & 0 & 0.02 & 0.23 \\
\hline Bursa- Mudanya & 0 & 0.07 & 0.08 & 0.13 & 0.12 & 0.06 & 0 & 0.02 & 0.21 \\
\hline Bilecik & 0 & 0.09 & 0.09 & 0.04 & 0 & 0.07 & 0 & 0.02 & 0.19 \\
\hline Adana & 0 & 0.22 & 0.11 & 1.20 & 0.26 & 0.56 & 0.15 & 0.02 & 0.22 \\
\hline Aydın & 0 & 0.16 & 0.09 & 0.76 & 0 & 0.17 & 0 & 0.03 & 0.24 \\
\hline Bolu-Yeniçăg & 0 & 0.06 & 0.04 & 0.13 & 0 & 0.18 & 0 & 0.02 & 0.22 \\
\hline Düzce-Gölkaya & 0 & 0.11 & 0.06 & 0.59 & 0.04 & 0.07 & 0 & 0.02 & 0.21 \\
\hline Çaycuma-Çiftlik & 0.11 & 0.09 & 0.07 & 0.27 & 0 & 0.16 & 0 & 0.02 & 0.23 \\
\hline Zonguldak-Ereğli & 0 & 0.07 & 0.08 & 0.01 & 0.30 & 0.11 & 0 & 0.02 & 0.21 \\
\hline Bartın & 0.09 & 0.10 & 0.09 & 0.36 & 0 & 0.35 & 0 & 0.02 & 0.24 \\
\hline Karabük & 0.24 & 0.07 & 0.10 & 0.01 & 0 & 0.24 & 0 & 0.02 & 0.22 \\
\hline Kastamonu & 0 & 0.11 & $\mathbf{0 . 1 4}$ & 0.36 & 0.24 & 0.23 & 0 & 0.02 & 0.21 \\
\hline Trabzon & 0.50 & 0.04 & 0.09 & 0.01 & 0 & 0.52 & 0 & 0.02 & 0.22 \\
\hline Erzurum & 0.14 & 1.45 & 0.02 & $\mathbf{1 1 . 5 6}$ & 0 & 0 & 0 & 0.02 & 0.18 \\
\hline Van & 0 & 0.26 & 0.12 & 1.90 & 0 & 0.14 & $\mathbf{0 . 7 6}$ & 0.03 & 0.19 \\
\hline Muş & 0 & 0.41 & 0.09 & 3.17 & 0 & 0.63 & 0.62 & 0.03 & 0.21 \\
\hline
\end{tabular}


In this study, Ca was low in content in the samples except for Sivas-Zara $0.34 \%$, while higher levels of $\mathrm{K}$ in propolis was collected from Kırıkkale $0.9 \%$, Adana $0.6 \%$, and Trabzon, AnkaraKızılcahamam, Sivas-Zara $0.5 \%$ are shown in the Table 2. In another study by Doğan et al., 2006, higher levels of $\mathrm{Na}$ was observed in propolis from Artvin, İzmir and Bursa region. $\mathrm{Mg}$ was similar content with the ranges of their study [20].

Silicon is a crucial element for human health that has proved to suppress many illnesses [29], in addition to the fact that $\mathrm{Si}$ content is quite high in Erzurum, Muş and Sivas as Erzurum 11\%, Mus 3\%, Sivas-Zara $1.8 \%$ in the current results is promising for propolis. Furthermore, the fact that the $0.5 \% \mathrm{Mg}$ content was found in the sample collected from Trabzon is remarkable, as it was $0.2 \%$ in Karabük and propolis samples from other provinces. Thus, it suggests that all cities have their own characteristic elements in propolis, with environmental conditions being effective in them.

Therefore, the concentration of heavy metals in propolis can reflect the contamination of the environment originating from emissions. Sulfur content of propolis was quite high in Zonguldak Ereğli $0.30 \%$, Sivas-Zara $0.29 \%$, Adana $0.26 \%$, Kastamonu $0.24 \%$, in addition to decreasing in other provinces which are shown in Table 2; this is remarkable as it indicates there is environmental pollution in those provinces [30]. Propolis may be used as an indicator of environmental contamination.

Table 3. Non-Parametric statistics used to calculate mean and standard deviation of elements in 22 raw propolis samples from different regions of Turkey.

\begin{tabular}{|c|c|c|c|}
\hline Elements & $\mathbf{N}$ & Mean \% & Std. Deviation \\
\hline $\mathrm{Na}$ & 22 & 0.2064 & 0.29240 \\
\hline $\mathrm{Al}$ & 22 & 0.0845 & 0.02773 \\
\hline $\mathrm{Si}$ & 22 & 1.2350 & 2.43748 \\
\hline $\mathrm{S}$ & 22 & 0.0682 & 0.10813 \\
\hline $\mathrm{K}$ & 22 & 0.2805 & 0.23868 \\
\hline $\mathrm{Ca}$ & 22 & 0.0868 & 0.21180 \\
\hline $\mathrm{Fe}$ & 22 & 0.0277 & 0.00456 \\
\hline $\mathrm{Mn}$ & 22 & 0.2145 & 0.01535 \\
\hline
\end{tabular}

Non-Parametric statistics were used to calculate mean and standard deviation for elements in samples (Table 3). Potassium content was at a higher level (mean: $0.2805 \pm 0.2386 \%$ ) in samples, while calcium concent was at a lower level (mean: $0.0868 \pm 0.21180$ ) in those from the studied regions of Turkey. 


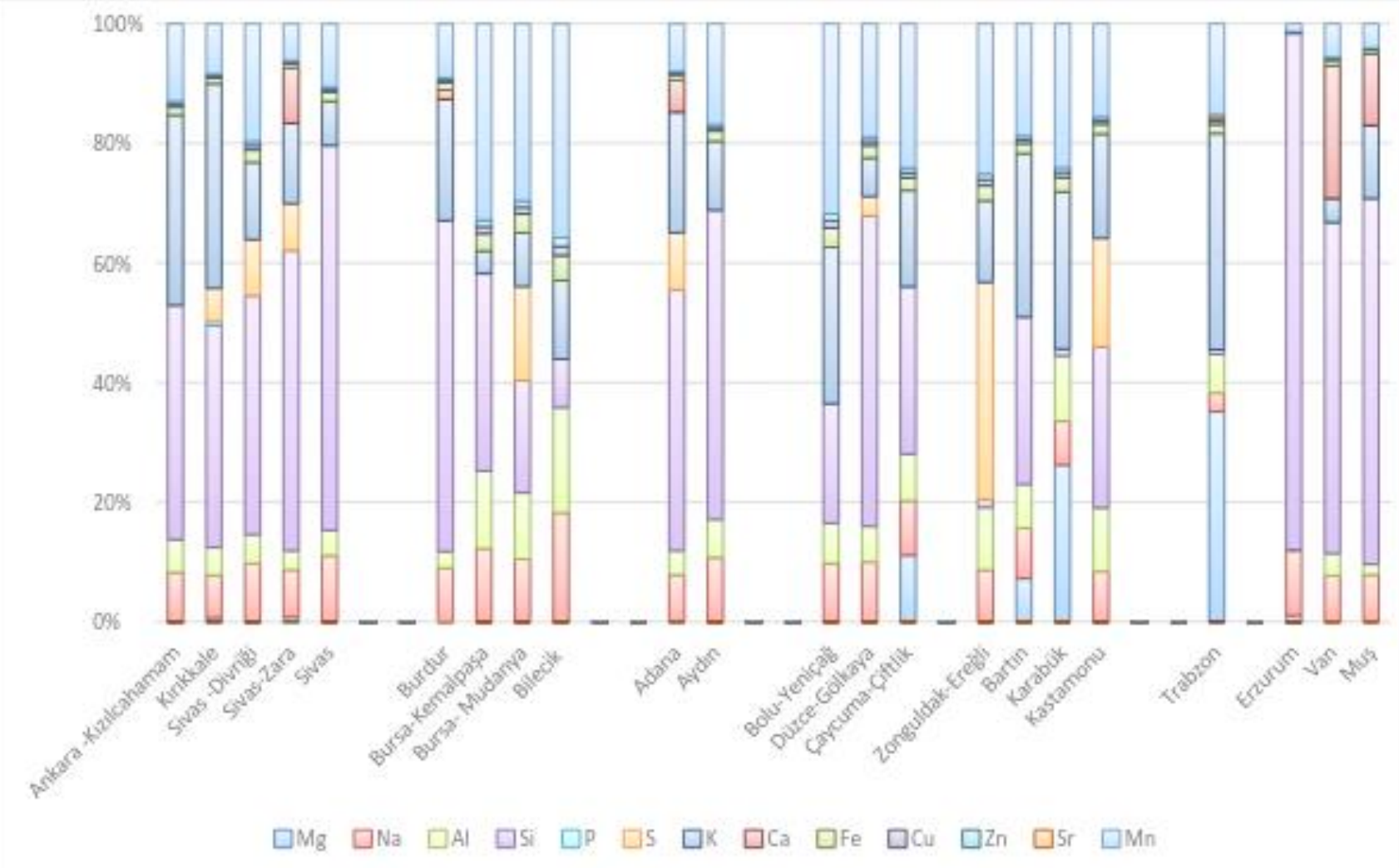

Figure 2. Percentage of component in 22 raw propolis samples from different cities in Turkey The copper content was at 0.0081 to $0.0082 \%$. $\mathrm{Cu}$ and $\mathrm{Zn}$ contents in propolis were within safe limits [30], and compared well with levels in foods from Turkish Food Codex, though Zn contents were high (Figure 2).

Propolis can contain heavy metals that can significantly affect the biological properties of derived product cDCA [31]. We revealed Al (mean: 0.845 \pm 0.02773 ) and Fe contents (mean: $0.0277 \pm 0.0456)$ were at lower levels than in the previous report [19]. However, it included high levels of Mn (mean: $0.2145 \pm 0.01535$ ) at low levels or the absence of heavy metals; as a result, propolis may be used as an indicator of environmental contamination [7].

Table 4. The comparision of differences for elements in 22 raw propolis samples from various region of Turkey by using Kruskal-Wallis test.

\begin{tabular}{|l|l|l|l|l|l|l|l|l|l|}
\hline & $\mathrm{Mg}$ & $\mathrm{Na}$ & $\mathrm{Al}$ & $\mathrm{Si}$ & $\mathrm{S}$ & $\mathrm{K}$ & $\mathrm{Ca}$ & $\mathrm{Fe}$ & $\mathrm{Mn}$ \\
\hline Chi-Square & 4,311 & 16,880 & 0,195 & 17,103 & 3,438 & 8,280 & 12,118 & 9,610 & 8,411 \\
\hline df & 5 & 5 & 5 & 5 & 5 & 5 & 5 & 5 & 5 \\
\hline Asymp. Sig. & 0,506 & 0,005 & 0,999 & 0,004 & 0,633 & 0,141 & 0,033 & 0,087 & 0,135 \\
\hline
\end{tabular}

A Kruskal-Wallis test was performed to compare differences in elements of 22 raw propolis samples from various regions of Turkey. According to the Kruskal-Wallis test results asymp. sig. value for $\mathrm{Na}, \mathrm{Si}$, and $\mathrm{Ca}$ was $\mathrm{P}<0.05$. Therefore, differences for these elements were statistically significant (Table 4).

Ca was at a high levels (frequency: 2> median) in samples from Meditarian region and Eastern Anatolia but at a low level (frequency: $8 \leq$ median) in samples from Black Sea region. Na was at a 
high level (frequency: 4> median) in samples from middle Anatolia but was at a low level (frequency: $8 \leq$ median) in samples from Black Sea region. Si was at a high level (frequency 4> median) in samples from middle Anatolia but it was at a low level (frequency: $7 \leq$ median) in samples from the Black Sea region. These propolis samples were rich in minerals of $\mathrm{K}$ and $\mathrm{Na}$, and can therefore be potentially more beneficial in human nutrition. The obtained results indicated there was no pollution in the provinces where these samples were collected.

The chemical content may be used to determine additional qualities of propolis samples. However, in addition to the analysis of natural propolis constitutents, elements and toxic contaminants such as heavy metals should also be a subject of chemical control [12].

In this study, the concentrations of three representative heavy metals (cadmium, chromium, and lead) were measured using atomic absorption spectroscopy. Samples were collected from six different sampling points: from six different geografic regions of Turkey. All apiaries employed for this study were specifically constructed without any metal parts in order to avoid the risk of contamination of the assayed materials. Lead (23.81-518.24 $\mu \mathrm{g} / \mathrm{kg})$, arsenic (17.88- 573.36 $\mathrm{mg} / \mathrm{kg}$ ), and cadmium $(1542-2441 \mu \mathrm{g} / \mathrm{kg}$ ) were found in these propolis samples (Table 5). Conti and Botre (2000) [32] determined lead as 1.06-4.32 ( $\mu \mathrm{g} / \mathrm{kg})$ and cadmium density as 0.62-6.59 $(\mu \mathrm{g} / \mathrm{kg})$.

Table 5. Heavy metal levels of propolis from six cities of Turkey

\begin{tabular}{|l|l|l|l|}
\hline Provinces & Pb $(\boldsymbol{\mu g} / \mathbf{k g})$ & As $(\boldsymbol{\mu g} / \mathbf{k g})$ & $\mathbf{C d}(\boldsymbol{\mu g} / \mathbf{k g})$ \\
\hline Zonguldak & 518.24 & 127.16 & 1817.00 \\
\hline Ankara & 42.14 & 41.26 & 1542.00 \\
\hline Bursa & 843.13 & 573.36 & 2385.00 \\
\hline Adana & 104.46 & 23.71 & 2437.00 \\
\hline Muş & 57.57 & 17.88 & 2441.00 \\
\hline Kastamonu & 23.81 & 52.69 & 1783.00 \\
\hline
\end{tabular}

Overall, experimental data revealed statistically significant differences between the background levels of heavy metals recorded from the reference sites. According to the results of the statistical analysis, significant differences were found between propolis samples in heavy metal values such as arsenic $(\mathrm{p}=0.030<0.05)$ and cadmium $(\mathrm{p}=0.002<0.5)$. As a result, cadmium has the highest values in propolis. In this study, propolis has high levels of heavy metals, as in previous studies [33]. These results indicate that propolis can be considered representative bioindicators of environmental pollution.

Final results indicate the usefulness of including metals in the characterization of propolis samples according to their origin, and could thereby be regarded as an indication of environmental pollution in the collection area in order to evaluate the potential of propolis for the development of new drugs.

The element patterns of propolis we have studied were sufficiently distinctive to make the discrimination of propolis from different locations in Turkey. However, it is possible this variation was influenced by different mineral composition of plants and numerous environmental factors (e.g., soil $\mathrm{pH}$, humidity, mobility of trace elements, etc.).

The results obtained from this work allowed us to conclude that the residues of heavy metals were a limited concentration in Turkish propolis samples. Their chemicals will not be determined 
until NMR analysis is conducted. Therefore, it is necessary to obtain additional structural confirmation to establish a more specific database of wild propolis from Turkey.

List of Abbreviation: EDXRF- energy-dispersive X-ray fluorescence spectrometre; NMR-Nuclear magnetic resonance; ANOVA-one-way analysis of variance

Competing interests: All authors have no competing of interest.

Author's contributions: All authors contributed to this study.

\section{REFERENCES}

1. Salatino A, Teixeira EW, Negri G et al (2005) Origin and chemical variation of Brazilian propolis. eCAM 2:33-38

2. Russo A, Cardile V, Sanchez F, Troncoso N, Vanella A. Chilean propolis: antioxidant activity and antiproliferative action in human tumor cell lines. Life Sci 2004, 76(5):54558.

3. Pagliarone AC, Missima F, Orsatti CL, Bachiega TF, Sforcin JM. Propolis effect on Th1/Th2 cytokines production by acutely stressed mice. Journal of Ethnopharmacology 2009, 125:230-233.

4. Valente MJ, Baltazar AF, Henriqu R, Estevinho L, Carvalho M. Biological activities of Portuguese propolis: Protection against free radical-induced erythrocyte damage and inhibition of human renal cancer cell growth in vitro. Food Chem Toxicol. 2011, 49(1):8692.

5. Ghisalberti EL, Jefferies PR, Lanteri R, Matisons J. Constituents of propolis. Experientia, 1978, 34(2):157-158.

6. Starks PT, Blackie CA, Tomas PT, Seeley D. Fever in honeybee colonies. Naturwissenschahen, 2000, 87(5): 229-231.

7. Wilson-Rich N, Spivak M, Fefferman NH, Starks PT. Genetic, individual, and group facilitation of disease resistance in insect societies. Annual Review of Entomology 2009, 54:405-423.

8. Cvek J, Medic-Saric M, Vitali D, Vedrina-Dragojevic I, Smit Z. The content of essential and toxic elements in Croatian propolis samples and their tinctures. Journal of Apicultural Research 2008, 47(1):35-45

9. Anjanette W, Gjertsen DDS, Stothz KA, Kathleen G, Neiva DDS. Effect of propolis on proliferation and apoptosis of periodontal ligament fibroblasts. Oral Surg Oral Med Oral Pathol Oral Radiol Endod 2011, 112:843-848.

10. Alday E, Valencia D, Carre no AL, Picerno P, Piccinelli AL. Apoptotic induction by pinobanksin and some of its ester derivatives from Sonoran propolis in a B-cell lymphoma cell line. Chemico-Biological Interactions 2015, 242:35-44.

11. Almutairi S, Edrada-Ebel R, Fearnley J, Igoli JO, Alotaibi W. Isolation of diterpenes and flavonoids from a new type of propolis from Suui Arabia. Phytochemistry letters 2014, 10:160-163.

12. Wolsky RG, Salatın A. Analysis of propolis: some parameters and procedures for chemical quality control. Journal of Apicultural Research 1998, 37(2):99-105.

13. Kardar MN, Zhang T, Coxon GD, Watson DG, Fearnley J, Seidel V. Characterisation of triterpenes and new phenolic lipids in Cameroonian Propolis. Phytochemistry 2014, 106:156-163.

14. Gencay Ö, Sorkun K. Microscopic analysis of propolis samples collected from east Anatolia (Kemaliye-Erzincan) FABAD J. Pharm. Sci. 2006, 31:192-197. 
14. Sorkun K, Süer B, Salih B. Determination of chemical composition of Turkish propolis. Z.Naturforsch 2001, 56c:666-668.

15. Silici S, Kutluca S. Chemical composition and antibacterial activity of propolis collected by three different races of honeybees in the same region. J. Ethnopharmacol. 2005a, 99:6973.

16. Silici S, Unlu M, Vardar-Unlu G. Antibacterial activity and phytochemical evidence for the plant origin of Turkish propolis from different regions. World J Microbiol Biotechnol. 2007, 23(12):1797-1803.

17. Uzel A, Sorkun K, Önçă̆ Ö. Chemical compositions and antimicrobial activities of four different Anatolian propolis samples, Microbiol Res. 2005, 160:189-195.

18. Silici S. Pre-clinical studies on propolis. Erciyes University Journal of Institue of Science and Technology 2015, 31(3):185-191.

19. Dogan M, Silici S, Saraymen R, Ilhan IO. Element Content of Propolis From Different Regions of Turkey. Acta Alimentaria 2006, 35(1):127-130.

20. Çelemli ÖG, Sorkun K Salih B. Chemical composition of propolis samples collected from Tekirdag-Turkey. Mellifera 2012, 12-24:27-32.

21. Gençay Ö, Salih B. GC-MS analysis of propolis samples from 17 different regions of Turkey, four different regions of Brazil an done from Japan. Mellifera 2009, 9(17):19-28.

22. Tong Z, Ruwid, O, Weam S, Al Mutairi S, Clements C. Chromatographic analysis with 21 different detectors in the chemical characterisation and dereplication of African propolis. Talanta 2014, 120:181-190.2014;120, 181-190.

23. Savaya A Analytical strategies fort he characterisation of samples of Brazilian propolis from different regions and species of bees. Propolis human and bee health Conference, June 16th-17 th, Glasgow, Scodland, page 34, 2016 (unpublished).

24. Popova M, Silici S, Kaftanoglu O, Bankova V. Antibacterial activity of Turkish propolis and its qualitative and quantitati ve chemical composition. Phytomedicine 2005, 12:221228.

25. Basdoğan G, Dastan T, Mergen Duymaz G, Erden Sönmezer Ö, Damarlı E, Alpat U, Atalay $Đ$. The Project to determine a characteristic map of Turkish propolis, Propolis human and bee health Conference, 2016; June 16 th-17 th Glasgow, Scodland, page 31.

26. Lima GG, Souza RO, Bozzi AD, Poplawska MA, Devine DM, Nugent MJD. Extraction 24 Method Plays Critical Role in Antibacterial Activity of Propolis-Loaded Hydrogels. Journal of Pharmaceutical Sciences 2016, 105:1248-1257.

27. Vardar-Ünlü G, Silici S, Ünlü M. Composition and in vitro antimicrobial activity of Populus buds and poplar-type propolis. World J Microbiol Biotechnol 2008, 24(7):0111017

28. Ma JF, Takahashı E. Effect of silicic acid on phosphorus uptake by rice. Plant Soil Sci. Plant Nutr. 1989, 35:227-234.

29. Lens P, Pol LH. (Eds.). Environmental technologies to treat sulfur pollution. IWA publishing 2000.

30. Bonhevi J, Orantes Bermejo F. Element content of propolis collected from different areas of South Spain. Environ Monit. Assese. 2013, 185: 6035-6047.

31.Marcucci,MC. Propolis: chemical composition, biological properties and therapeutic activity. Apidologie 1995, 26(83):89.

32. Conti M, Botrè F. Honey bees and their products as potential bioindicators of heavy metals contamination. Environmental Monitoring and Assessment 2000, 69:267-282.

33. Sales A, Alvarez A, Areal M, Maldonado L, Marchisio P, Rodr'iguez M Bed, Ascarrasbure E. The effect of different propolis harvest methods on its lead contents determined by et aas and uv-viss. Journal of Hazardous Materials A137 2006, 1352-1356. 